Winter 2012

\title{
Harmonization, But Not Homogenization: The Case for Cuban Autonomy in Globalizing Economic Reforms
}

Heather Shreve

Indiana University Maurer School of Law, heshreve@indiana.edu

Follow this and additional works at: https://www.repository.law.indiana.edu/ijgls

Part of the Comparative and Foreign Law Commons, International Law Commons, and the Law and Economics Commons

\section{Recommended Citation}

Shreve, Heather (2012) "Harmonization, But Not Homogenization: The Case for Cuban Autonomy in Globalizing Economic Reforms," Indiana Journal of Global Legal Studies: Vol. 19 : Iss. 1 , Article 14. Available at: https://www.repository.law.indiana.edu/ijgls/vol19/iss1/14

This Note is brought to you for free and open access by the Law School Journals at Digital Repository @ Maurer Law. It has been accepted for inclusion in Indiana Journal of Global Legal Studies by an authorized editor of Digital Repository@Maurer Law. For more information, please contactrvaughan@indiana.edu.

\section{$\Psi$}

JEROME HALL LAW LIBRARY

INDIANA UNIVERSITY

Maurer School of Law
Bloomington 


\title{
Harmonization, But Not Homogenization: The Case for Cuban Autonomy in Globalizing Economic Reforms
}

\author{
HEATHER E. SHREVE*
}

\begin{abstract}
Since 1959, Cuba has been an anomaly in the Western Hemisphere. From its fierce isolationism to its steadfast commitment to communism and Fidel Castro, the Cuban model shunned many modern conventions and developments of the increasingly globalized world. However, in the last decade, subtle shifts in Cuban governance and control led some scholars to question if and how Cuba could participate in the modern, global economy. President Raúl Castro answered the speculation in late 2010 with an announcement regarding Cuban economic modernization and, again, in 2011, as significant economic reforms were implemented. All of these changes beg the ultimate question: Can Cuba engage and interact with the global economy and remain a Marxist-Leninist philosophy, or is an irreversible, fundamental homogenization required? This Note argues that, based on the basic principles of globalization, it is possible for Cuba to enter the globalized economy and to harmonize, rather than homogenize, their economic policies with those of other countries while retaining its Marxist-Leninist philosophy. Globalization unavoidably and transformatively requires all global actors to harmonize their policies but does not require homogenization or uniformity.
\end{abstract}

\section{INTRODUCTION}

In 2010 , when asked by a reporter about the value of spreading the Cuban model to other countries, Fidel Castro responded, "[t]he Cuban

* Executive Articles Editor, Indiana Journal of Global Legal Studies; J.D. Candidate, 2012, Indiana University Maurer School of Law. I would like to thank Professor Alfred C. Aman, Jr. for his guidance throughout the writing and editing processes. I would also like to thank John Fleming for his unfailing support. Unless otherwise noted, all translations are my own.

Indiana Journal of Global Legal Studies Vol. 19 \#1 (Winter 2012)

(C) Indiana University Maurer School of Law 
model doesn't even work for us anymore." 1 This statement, while certainly an offhand remark from the revolutionary Cuban leader, is, at minimum, an acknowledgment of Cuba's difficulties over the last decade. As interpreted by some commentators, Castro's statement was an "acknowledgement that under 'the Cuban model' the state has much too big a role in the economic life of the country."2 Shortly after the publication of Fidel Castro's remark, Cuban President Raúl Castro announced that the National Congress of the Communist Party of Cuba would convene in April 2011 after a fourteen-year hiatus to "make fundamental decisions on how to modernize the Cuban economic model and adopt the paths for economic and social policy of the party and the revolution."3

These two events culminate years of economic struggle and recent structural economic reforms in Cuba, including plans to lay off a halfmillion state workers; to allow citizens to start private businesses as employers hiring employees; 4 and to reduce the government's role in financing free education, free health care, and nearly free housing. ${ }^{5}$ Based on these developments, it could be speculated that Cuba, the last stronghold of purely Marxist-Leninist ideology and structure, must finally conform and liberalize its economic policies to join the globalized economy after almost sixty years of isolationism. While it seems that economic liberalization is an unlikely end result, the proposed economic reforms are significant, as it was once thought that such change could only occur after intense structural alternations to the Cuban ideological model. 6

Larry Catá Backer, a professor of law at Pennsylvania State University, provides an important perspective on the possibility of a

1. Jeffrey Goldberg, Fidel: 'Cuban Model Doesn't Even Work for Us Anymore', ATLANTIC (Sept. 8, 2010, 12:00 PM), http://www.theatlantic.com/international/archive/2010/09/fidelcuban-model-doesn't-even-workfor-us-anymore/6202/.

2. Id. (noting the comment of Julia Sweig, an eminent Latin American scholar at the Council on Foreign Relations, with whom Goldberg traveled to meet Castro). at $\mathrm{A} 9$.

3. Cuba to Hold Party Congress to Chart Path for Economy, N.Y. TIMES, Nov. 8, 2010,

4. Id.

5. Id.

6. In the proceeding months to the publication of this Note, the Cuban government has undertaken a series of planned reforms, including, but not limited to allowing limited private property ownership and the continued expansion of controlled self-employment. See, e.g., Damien Cave, Cuba to Allow Buying and Selling of Property, With Few Restrictions, N.Y. TTMES, Nov. 3, 2011, at A4; Nick Miroff, Entrepreneurs Emerge As Cuba Loosens Control, NPR (Sept. 20, 2011), available at http://www.npr.org/2011/09/20/140501399/entrepreneurs-emergeas-cuba-loosens-control. Nevertheless, these reforms do not undermine the central thesis of this Note, as explored below, as the continuation, expansion, and longevity of further reform is yet unknown. 
globalized Cuba. In 2004, Backer published a paper in which he considered whether Cuba could "remain true to its Marxist-Leninist principles of political and economic organization, and simultaneously embrace the emerging system of economic globalization."7 Ultimately, Backer concluded that, while globalization is likely inevitable for Cuba, ${ }^{8}$ the state cannot and will not embrace it without "ambitious reform," including an abandonment of the "inflexibility" 10 of the foundational system of Cuba-the Cuban model of Marxist-Leninist principles, or "Fidelismo."11

In the seven years since the publication of Backer's article, Cuba experienced drastic political, cultural, and economic changes; among the most notable is the change in leadership in July 2006 from Fidel Castro, ${ }^{12}$ the bedrock of the Cuban revolution and the visionary of the Marxist-Leninist state, to Raúl Castro, his younger, more open-minded brother. Under the leadership of Raúl Castro, the government enacted structural and ideological reforms and opened up dialogue regarding the future of Cuba. For example, the government is more welcoming of foreign investment, wage changes, instituting a singular form of currency, and, most recently, self-employment and cooperative ownership of businesses..$^{13}$ In addressing these changes, some suggest China as a possible source of inspiration; ${ }^{14}$ meanwhile, the Cuban government remains staunchly independent, stating that " $[t]$ he official mantra is that rather than copying any foreign model, policy changes will comprise 'a Cuban response to the Cuban reality." 15 With a patchwork of economic changes enacted and the guidelines from the April 2011 little more than the proposed changes upon which to speculate until April 2011, the motivation and the ultimate product of these reforms fascinate those on the outside.

7. Larry Catá Backer, Cuban Corporate Governance at the Crossroads: Cuban Marxism, Private Economic Collectives, and Free Market Globalism, 14 TRANSNAT'L L. \& CONTEMP. PROBS. 337, 338 (2004).

8. Id. at 411 .

9. Id. at 417 .

10. Id. at 386 .

11. Id. at 390,413 .

12. Raúl's Talking Cure: Pointers to a Coming Liberalisation, ECONOMIST, Oct. 25, 2007, available at http://www.economist.com/node/10026212 [hereinafter Raul's Talking Cure].

13. Id.

14. See Cuba Inspired by China's Economic Reform, Top Official Says, Fox NEwS LATINO (Nov. 24, 2010), http://atino.foxnews.com/latino/politics/2010/11/24/cuba-inspiredchinas-economic-reform-official-says/ [hereinafter Cuba Inspired by China's Economic Reform].

15. Id. 
In response to these changes, some commentators argue that with such large, sweeping changes, Cuba is coming to terms with the failure of its Marxist-Leninist ${ }^{16}$ form of governance and will exchange it for the Chinese Maoist model of a "socialist market economy,"17 or will start to take steps to establish democracy and free trade in Cuba. ${ }^{18}$ These arguments, while certainly interesting, fail to take into account two possible factors: first, that rather than a sign of defeat and an embrace of a new ideology, the change in Cuba is a reaction borne of necessity in the globalizing world, and second, that fiercely autonomous Cuba will not adopt a model of governance contrary to its very ideology and core, such as the market socialism and neoliberal models. Instead, Cuba is attempting to carve out its own niche within the realm of globalization on its own terms.

Although the end result of the Cuban economic reforms remains unknown, Cuba serves as an illustration of the limitless flexibility of globalization to create linkages, interplay, and engagement between the global economy and the state-even an ideological state that would be thought to resist globalization. In short, Cuba's economic reforms buck the assumption of many theorists that Cuba could not or would not globalize and show that, in globalization, the state reconfigures itself to be a global actor and to engage in various models of engagement. No state is immune from globalization; however, not all states must globalize in the same model.

16. Hallmarks of Marxist-Leninist governance are the following:

The first . . . is one of national security: the power of the state must be consolidated and increased in order to discourage the enemies of socialism from attacking the Soviet regime and to assure peaceful coexistence between nations. Soviet law has, in addition, the economic task of developing production on the basis of socialist principles so as to create the abundance which alone will enable everyone to be supplied "according to his needs." The third task of Soviet law is one of education: that is, to destroy in Man those tendencies to selfish and antisocial behavior that are the heritage of centuries of poor economic organization.

RENÉ DAVID \& JOHN E.C. BRIERLEY, MAJOR LEGAL SYSTEMS IN THE WORLD TODAY 176 (2d ed. 1978).

17. The Chinese Maoist model differs from the traditional Marxist-Leninist in that "[c]itizens, along with the state (representing the collective), can now both engage in economic activity, subject always to the right of the state to intervene." Backer, supra note 7 , at 376 .

18. Raúl the Pragmatist: Bold Changes Intended to Preserve Cuban Communism May Herald the Beginning of its End, EcoNOMIST, Nov. 11, 2010, available at http://www.economist.com/node/17463463 [hereinafter Raul the Pragmatist] ("In the meantime, [Castro's] new boldness represents an opportunity for those who hope that Cuba will eventually join the rest of Latin America in accepting democracy and the market economy, for once the market's green shoots appear they tend to flourish."). 
Globalization, in short, is a transformative process by which forces at all levels, from local to international, exert pressure on the decisionmaking process of states to harmonize with the policies and the practices of other countries; however, while this results in similarities, globalization is not homogenization. Therefore, it is possible for Cuba to enter the globalized economy and to harmonize their economic policies with those of other countries while retaining its Marxist-Leninist philosophy.

The purpose of this Note is to illustrate that an ideological state, such as Cuba, can play a role in a globalized world by reconfiguring itself into an involved global actor-albeit an actor who may operate differently in the global forum. Part I provides background information on globalization, Cuba, and the 2004 work of Larry Catá Backer regarding globalization in Cuba. Part II considers fundamental changes in Cuba and the global economy since 2004 that surround the implementation of Cuban reform policies. Part III analyzes three theories behind the changes in Cuba through the lens of globalization and presents lessons regarding globalization learned from the case study of Cuba. Ultimately, while Cuba may decide to implement an economic system that mirrors Maoist China or neoliberal policies favored by the West, this implementation is not required by globalization, leaving open the question of whether it is plausible for a country to selectively engage globalization on its own terms or whether globalization is so pervasive a force as to preclude such an option; the final part of this paper presents guidelines to help Cuba successfully globalize in a way consistent with its ideology.

\section{BACKGRound: PRINCIPLES OF GLOBALIZATION, CUBA, AND THE 2004 ANALYSIS}

To truly understand the potential economic upheaval awaiting Cuba, it is first crucial to fully grasp the concept of globalization and its relationship with Cuban economic reform. As such, this part shall explore background information with respect to the general principles of globalization and the history of Cuba's economy and give a brief overview and an analysis of Larry Catá Backer's work regarding Cuba and globalization.

\section{A. Principles of Globalization; Globalization as Harmonization}

Globalization refers to various transformative changes and processes that permeate and unite all levels of governance, from local to international. There are myriad ways to conceptualize the many facets 
of globalization: for example, as a continuum with social and economic relations and networks for the local scale on one side and the global scale on the other. ${ }^{19}$ Over this continuum, human affairs link together and expand at all levels; ${ }^{20}$ within this continuum, human affairs are linked through various processes that transform "spatial organization of social relations and transactions-assessed in terms of their extensity, intensity, velocity, and impact-generating transcontinental or interregional flows and networks of activity, interaction, and the exercise of power."21 Certainly, while some uniformity results from this process, it is the linkages themselves that are the most important to our study of globalization.

It is first critical to recognize where, within the pantheon of globalization, this Note explores. In contrast to this Note's definition and usage of globalization, several different theories of globalization exist and, at one time, dominated the study of globalization. ${ }^{22}$ Two overarching principles from these models should be noted in the context of this Note. First, there is an assumption that all states must, willingly or unwillingly, modernize $e^{23}$ through linear development of industrial economic policies. Therefore, to reach an economic level of development to be fully modernized, a state must fulfill certain economic conditions, such as committing itself to capital mobilization and entrepreneurship, compromising certain societal values to allow for modern efficient production, and increasing the standard of living and mass consumption. $^{24}$ Second, from this assumption, it follows that, as economic modernization occurs, a state's society will assent to the new,

19. David Held et al., Rethinking Globalization, in The Global Transformations READER: AN INTRODUCTION TO THE GLOBalization Debate 67, 67 (David Held \& Anthony McGrew eds., $2 d$ ed. 2003).

20. Id.

21. Id. at 68.

22. See, e.g., Alexander Gerschenkron, The Early Phases of Industrialization in Russia: Afterthoughts and Counterthoughts, in THE ECONOMICS OF TAKE-OFF INTO SUSTAINED GROWTH 151, 151-69 (W.W. Rostow ed., 1963); W.W. Rostow, Preface to the Third Edition of W.W. Rostow, The STAGES OF ECONOMIC GROWTH: A NON-COMMUNIST MANIFESTO (3d ed. 1990).

23. See RosTow, supra note 22 , at $\mathrm{xxv}$ ("[S]ocieties that deny themselves modernization also leave themselves open to intrusion, and soon or late they may be driven to accept the world of modern technology .... . Contemporary countries that have not yet entered takeoff do not, on balance, represent a group trying to fashion viable traditional societies in revolt against the costs and distortions of modern life . . . they all reflect failures to achieve avowed modernizing objectives, selected after the believed costs and benefits had been weighed.").

24. See id. at 4-11 (describing the Rostovian take-off model, which traces the linear progression of a nation from a traditional society to the age of mass consumption); see also Backer, supra note 7, at 352-54. 
materialistic norms that follow from modernization. ${ }^{25}$ Ultimately, the more "backward" a state's economy is in comparison to the modern, industrialist economy, the more certain it is that particular conditions must be fulfilled for development and change. ${ }^{26}$

These antiquated, simplistic models of globalization are vestiges of a "one world," homogenous view of global economic interaction. However, as time has progressed, it is clear that neither globalization nor global economic engagement requires uniformity and conformity of states. Whereas this Note asserts that global economic engagement does not require homogenization of economic and societal values but is infinitely flexible and can accommodate different models of engagement, these other theories of globalization avow that globalization can only function in a singular model and that states, which desire to engage in the global economy, must conform to that singular model, thus precluding the possibility of an ideological state, such as Cuba, from inclusion and engagement.

While a one world model precludes the role of the state, instead focusing on uniformity in economic progress and policy in all nations, it is clear that this is an inaccurate assessment of the role of the state in a globalized world. Instead, the state continues to play a rolealbeit reconfigured to remain in power-in the globalized world. Indeed, state power is "decentered" 27 in an interconnected world, as problems and global actors are increasingly transterritorial, ${ }^{28}$ and yet, states are not sidelined in the global scheme. States are required to engage with other global actors-other states, world organizations, and transnational corporations-in the decision-making process. The decision-making process is no longer made in a vacuum by a wholly sovereign body.

While it is undisputed that all state decision-making is influenced, to some extent, by other global actors, the manner in which states choose to engage the global community varies. Indeed, no state is

25. See id. at 9 ("The society makes such terms as it will with the requirements of modern efficient production, balancing off the new against the older values and institutions, or revising the latter in such ways as to support rather than to retard the growth process.").

26. See Gerschenkron, supra note 22, at 151-69 (describing the six degrees of backwardness and how each distinctly impacted the development of the economy). Gerschenkron depicts the "great spurt" that backwards countries experience as (1) a sudden and rapid increase in the rate of manufacturing growth and (2) a continuation of that growth through a period of international depression. Id. at 163.

27. Alfred C. Aman, Jr., The Globalizing State: A Future-Oriented Perspective on the Public/Private Distinction, Federalism, and Democracy, 31 VAND. J. Transnat'L L. 769, 772 (1998).

28. Id. 
immune from globalization, no matter how resistant it may be to dominant models of globalization, for globalization infuses and permeates all levels of society and government through linkages. Therefore, one may consider globalization as:

[T] he intensification of worldwide social relations which link distant localities in such a way that local happenings are shaped by events occurring many miles away and vice versa . . . . Local transformation is as much of a part of globalization as the lateral extension of social connections across time and space. ${ }^{29}$

Through all of these relations and linkages, although they vary by state, the reconfiguration of the state as a global actor allows it to remain in power by the way in which it chooses to globalize.

Ultimately, states retain their importance, even in a decentralized, globalized economy, as the linkage and permeation of governments, cultures, and countries do not necessarily lead to mindless uniformity in policy making. Instead, globalization provides incentives for states to harmonize their policies with others in the global economy and to "achieve some level of concordance with other legal systems." ${ }^{30}$ In this context, globalization decentralizes the very policies and theoretical underpinnings of governments allowing for concordance between nations that contain vastly different ideologies, ${ }^{31}$ as with the United States and China. Globalization may change the way in which states make decisions, but it is the state itself that implements its policies; ${ }^{32}$ a role remains for states within a globalized world, albeit in a different form. ${ }^{33}$

Rather than the linear, uniform models of one world globalization, the reconfigured state may globalize in its own way. All said, Cuba is a fascinating case study in the role of the globalizing state, for, despite the ideological reasons why Cuba would remain isolated, it instead is globalizing and doing so by its own model.

29. Anthony Giddens, The Globalizing of Modernity, in THE GLOBAL Transformations Reader: AN INTRoduction to the Globalization Debate 60, 60 (David Held \& Anthony McGrew eds., 2003).

30. Backer, supra note 7 , at 354 .

31. See id.

32. See Aman, supra note 27, at 803 (asserting that market economies are not motivated by the difficulties involved with regulation but rather by an affirmative decision by the state to reimpose a laissez-faire economy).

33. See, e.g., id. at 782 . 


\section{B. Cuba}

The Republic of Cuba, located in the Caribbean Sea, is home to 11.2 million people and, since January 1, 1959, is the first Communist government in the Western Hemisphere. ${ }^{34}$ Cuba stands as an anomaly in much of the world, as its geographical location, an island, allows it to be one of the most isolationist countries in the world. For the first part of Cuba's history under the Cuban Communist Party, it received support from and maintained relations with the Soviet Union, until its fall in $1991 .^{35}$ As a result of the loss of Soviet support, the Cuban economy suffered, and its GDP declined by thirty-five percent between 1990 and 1993; this suffering was compounded by the ideological and geographical isolation of Cuba from the global community. ${ }^{36}$ Although liberal reforms implemented between 1993 and 2003 opened up certain economic and cultural relationships with the global community, Cuba has resisted many of the modern trends of the remainder of the world. ${ }^{37}$

Currently, Cuba's economy navigates troubled waters. Statistically, the 2009 GDP is officially estimated at $\$ 51.01$ billion, and the GDP per capita is $\$ 4,545.00 ; ;^{38}$ the current monthly wage is around $\$ 19.00 ; ;^{39}$ and the average nominal salary from 2000 to 2007 increased twice as much as productivity. ${ }^{40}$ The Cuban government remains the largest employer of the five million person workforce, with the state employing about eighty-three percent of the workforce, and another five percent of the labor force employed by state-connected cooperatives. ${ }^{41}$ Meanwhile, the private workforce remains stunted, employing a mere twelve percent of the population, with self-employment constituting three percent-a mere 142,000 individuals - of the total workforce. ${ }^{42}$ In addition to the large burden of being the country's main employer, the Cuban state also faces economic concerns regarding its lack of productivity, as sixty percent of the workforce is in a non-productive sector and as imports are equivalent to four times the value of exports. ${ }^{43}$ Beyond economic

34. Background Note: Cuba, U.S. DEP'T OF STATE (Apr. 28, 2011), http://www.state.gov/r/ pa/ei/bgn/2886.htm; Cuba Country Profile, BBC News (Nov. 30, 2011), http://news.bbc.co.uk/ 2/hi/americas/country_profiles/1203299.stm\#facts.

35. Id.

36. $I d$.

37. Id.

38. Id.

39. Joaquín P. Pujol, The Cuban Economy in a World of Uncertainty, 19 CUBA IN TRANSITION 1, 3 (2009).

40. Id. at 2 .

41. Background Note: Cuba, supra note 34 .

42. Id.

43. Id.; Pujol, supra note 39 , at 2 . 
stagnation, other economic changes include those caused by the United States embargo," "lower sugar and nickel prices, increases in petroleum costs, devastating hurricanes in 2001, 2004, and 2008, a major drought in the eastern half of the island, increasing external debt, and stagnant or decreasing agricultural and industrial productivity,"45 all of which ultimately result in a bleak economic outlook for Cuba. ${ }^{46}$

Due to these economic struggles, the Cuban economy is weak; as the GDP falls, the deficit grows and the government increasingly depends on food and energy imports and the service sector, all of which is dependent and reliant on international cooperation. ${ }^{47}$ Additionally, the continued United States economic embargo against Cuba stifles potential economic growth, despite calls by the international community for it to be lifted. ${ }^{48}$ Recently, leaked confidential U.S. diplomatic cables predicted that Cuba's economic and financial situation could be "fatal" by 2012 or 2013 due to the global financial crisis and foreign debt. ${ }^{49}$ It is clear that economic change is necessary if Cuba is to remain afloat; it is equally clear that such changes have begun.

\section{Cuba and Globalization: Larry Catá Backer, 2004}

In 2004, Larry Catá Backer published "Cuban Corporate Governance at the Crossroads: Cuban Marxism, Private Economic Collectives, and Free Market Globalism," a piece that considered whether Cuba could globalize economically while remaining ideologically committed to a

44. See Overwhelming Majority of Nations Reiterate Their Rejection of the Blockade Against Cuba, GRANMA INT'L (Cuba) (Oct. 26, 2010), http://www.granma.cu/ingles/newsi/26octubre-43rechazo.html (estimating that the U.S. embargo on Cuba has generated losses worth $\$ 751,363$ billion since its enactment).

45. Background Note: Cuba, supra note 34 .

46. See Pujol, supra note 39 , at 3 (citing the statistic that Cuba imports more than eighty percent of its food supply).

47. Joaquín P. Pujol, "Cuba at the Crossroads in 21st Century": The Cuban Economy as Seen by Economists Within the Island and Other Observers, UNIÓN LIBERAL CUBANA, www.cubaliberal.org/economia/pdfs/Cubaneconomyin21st.pdf (last visited Sept. 26, 2011) (citing Cuba's reliance in trade upon Venezuela).

48. For example, in 2010, a resolution in the United Nations General Assembly called for the embargo to be lifted; it passed for the nineteenth consecutive year with a vote of 187 to 2 . Neil MacFarquhar, Assembly Again Urges U.S. to Lift Cuba Embargo, N.Y. TIMES, Oct. 27, 2010, at A8; see also G.A. Res. 65/41, U.N. Doc. A/RES/65/L.3 (Oct. 14, 2010); In Annual Vote, General Assembly Calls for Lifting United States Embargo Against Cuba, U.N. NEws CENTRE (Oct. 26, 2010), http://www.un.org/apps/news/story.asp?NewsID=36567\&Cr=Cuba\&Cr1.

49. Jens Erik Gould, Cuba's Economy May Become 'Fatal' in 2 Years, U.S. Cable Says, BloOMBERG (Dec. 10, 2010, 3:21 PM), http://www.bloomberg.com/news/2010-12-10/cubadebt-load-may-become-fatal-to-economy-in-two-years-u-s-cable-says.html. 
Marxist-Leninist philosophy. ${ }^{50}$ In his analysis, Backer considers whether the Cuban model could enter the global market in a manner similar to that used by the Chinese. ${ }^{51}$ Ultimately, Backer concludes that globalization is necessary for the future of $\mathrm{Cuba}^{52}$ but that it cannot happen, even in a manner similar to China's, without fundamental changes to the Cuban ideology and structure of governance.

Backer's analysis of the Cuban economy starts with the understanding that globalization is essential ${ }^{53}$ and inevitable for Cuba, despite its best attempts to resist. ${ }^{54}$ Based upon this understanding, he then considers whether Cuba could globalize in a manner similar to a successful Communist state: China. China's "controlled" engagement with the global economy, begun in 1978, experienced much success, starting especially in the $1990 \mathrm{~s}^{55}$ when the government blended together Maoism with liberalized economic policies making "it possible for Maoist China to embrace globalization without losing the state's basic Maoist character." ${ }^{\text {"C }}$ China's system has enjoyed obvious success as a "socialist market economy," a system that propelled China to the third-largest economy in the world in 2010, with a sustained economic growth of almost ten percent for almost three decades. ${ }^{57}$ Despite the strengths and successes of the Chinese hybrid system, it does not necessarily translate to success in Cuba.

Although it is tempting to analogize China's success to Cuba's due to common Communist underpinnings, Backer contends that Maoism is not the "Fidelismo" of Cuba and that significant differences exist between the two countries. ${ }^{58}$ To begin, today's world vastly differs from that of the beginning of the Cuban revolution, as globalization harmonizes the policies of the majority of the world; while the Chinese government embraced the "free enterprise entity-based bureaucratism" 59 and was received eagerly by the world without requiring change, ${ }^{60}$ Backer contends that Fidelismo does not embrace

50. Backer, supra note 7, at 338 .

51. $I d$.

52. Id. at 411 ("It is unlikely that Cuba will be able to resist the globalization consensus for long. Global harmonization produces pressures that nations like Cuba may find difficult to resist.").

53. Id. at 364 (explaining that "failure to adhere to the new orthodoxy of globalization .

. . can mean exclusion from the global community.").

54. See id. at 408-09.

55. See id. at $380,388$.

56. Id. at 386.

57. Background Note: China, U.S. DEPT. STATE (Sept. 6, 2011), http://www.state.gov/r/ $\mathrm{pa} / \mathrm{ei} / \mathrm{bgn} / 18902$.htm.

58. See Backer, supra note 7, at 385.

59. Id. at 396.

60. Id. at 399. 
such ideals and, moreover, that the West would not be so welcoming without demanding compromise. ${ }^{61}$

Following his analysis, Backer described several changes that would be necessary for Cuba to embrace globalization. The first is to decentralize the state from the economy, as was done in China, and to integrate Cuba into the global economy. ${ }^{62}$ The second is a change of the country's leadership from Fidel Castro, whom Backer described as fervently committed to the Marxist-Leninist philosophy, to Raúl Castro; the failure to do this would result in a lack of change in the government, as elites are unwilling to change, and an increased possibility of instability. ${ }^{63}$ Finally, Backer suggests that Cuba must re-evaluate its original vision of governance, perhaps adopting a more market-based approach, as capitalism, which, in the words of Lenin, "compels all nations, on pain of extinction, to adopt the bourgeois mode of production ... . In one word, it creates a world after its own image." ${ }^{14}$ Only through a "shift of focus" does Baker believe that Cuba can globalize as it must while still retaining its Marxist-Leninist philosophy. ${ }^{65}$

\section{Fundamental Changes in Cuba AND the World Since 2004}

Despite Backer's assertion that Cuba, as a state, must relinquish its power and conform to a prevalent form of engagement, such as capitalism, Cuba has since shown that it will globalize without doing so. Instead, Cuba is a global actor by its own choice, without withering as a state, and by creating its own model of engagement in conformance with its ideology. Indeed, Cuba cannot and will not resist globalization; it must globalize to survive. And yet, while Cuba globalizes, it does so in its own manner, in accordance with its own history, culture, and ideology.

\section{A. Changes in Cuba}

\section{The Rise of Raúl: Changes from 2004 to 2011}

Even before the announcement of the sixth National Congress of the Communist Part of Cuba and the economic reform, other major changes

61. See id. at 385,399 (describing how "Cuba could not remain true to its Stalinist principles and permit the creation of entities or juridical persons with independent control over fundamental attributes of state power").

62. See id. at 413 .

63. See id. at 417.

64. Id. at 404 (citing Karl Marx \& Friedrich Engels, The Communist Manifesto, in THE MARX-ENGELS READER 338-39 (1972)).

65. See id. at 414-17. 
occurred over the previous seven years in Cuban policy-many of which precede the current economic proposals and provide context to the everchanging and globalizing world surrounding Cuban decision-making. The accession of Raúl Castro as president, following Fidel Castro's illness in July 2006, marked the beginning of open acknowledgement of the struggling Cuban economy and a call for "open debate" regarding "structural and conceptual changes" that needed to occur. ${ }^{66}$ Within the first few years of Raúl's presidency, changes allowed Cubans to embrace limited forms of consumerism by purchasing mobile phones and staying in tourist hotels ${ }^{67}$ and to increase autonomy by permitting private farmers to buy supplies and equipment to increase the use of land.68 Although the initial reforms seem minor, larger reforms followed in 2008 , as the Cuban government implemented new policies that expanded access to public land for farming, increased wages, raised the retirement age, and modernized the infrastructure of transportation. ${ }^{69}$

Many of the changes implemented and issues raised for debate by Raúl Castro show the vast differences between his leadership and philosophy with that of Fidel Castro. To begin, Raúl Castro's role as the former defense minister, ${ }^{70}$ the most profitable state agency, ${ }^{71}$ lends itself to an entirely different manner of governance, one in which Castro "takes the view that Cuba can no longer afford the bloated and paternalistic state he inherited from Fidel, and the state's payroll should be linked to productivity." 72 Included in Castro's goal for increased productivity are a restructuring of the economy, a reduction in spending on universal education and healthcare, phasing out ration book to be replaced with targeted help, and "granting wide autonomy to state companies" with expectations that they will "pay their own wayand [be] liquidated if they do not," and can "set up joint ventures with foreign companies" to create jobs. ${ }^{73}$ These changes, while marking change in Cuba, show the Cuban state reconfiguring itself, albeit out of necessity, to remain an actor within the globalized world. Although changes exist, they are done in the context and by the power of the

66. Raúl's Talking Cure, supra note 12.

67. Big Brother's Shadow: Raúl Castro Preaches Patience, ECONOMIST, July 31, 2008, http://www.economist.com/node/11848468?story_id=11848468.

68. See id.

69. Background Note: Cuba, supra note 34.

70. Trying to Make the Sums Add Up, ECoNomisT, Nov. 11, 2010, http://www.economist.com/node/17463421.

71. See id. (revealing that according to Raúl's son-in-law, a military colonel, an armed forces holding company, called "GAESA," arguably controls up to forty percent of the Cuban economy).

72. Id.

73. Id. 
Cuban government, not in accordance with the U.S. or Chinese model of state engagement.

\section{The Turning Point: The Sixth National Congress of the Communist Party of Cuba and Economic Reform}

In November 2010, Raúl Castro announced that Cuba would hold the sixth National Congress of the Communist Party of Cuba in April 2011, after a fourteen-year hiatus, to "make fundamental decisions on how to modernize the Cuban economic model and adopt the paths for economic and social policy of the party and the revolution." 74 In addition to the announcement, the Cuban government released the "Economic and Social Policy Development Project" (Proyecto de Lineamientos de la Política Económica y Social del Partido y la Revolución), a thirty-two page booklet that presents the government's plans. ${ }^{75}$ The ultimate aim of these reforms is, in the words of Raúl Castro, to prevent Cuba from falling "off a cliff" due to economic disaster. ${ }^{76}$ More specifically, the plan intends "to boost exports and reduce reliance on imports, and to unify Cuba's twin currencies of worthless domestic pesos and stronger 'convertible' ones." "7

The specific points of the plan include an economic management model and policies for macroeconomics, foreign affairs, science, technology and innovation, health, education and employment, agribusiness, industry and energy, tourism, transportation, housing and water resources, and trade. ${ }^{78}$ Despite the wide range of changes to be implemented and mounting commentary that such "bold changes ... may herald the beginning of [Cuban communism's] end,"79 the plan itself states that " $[t]$ he economic policy in this new phase will follow the principle that socialism is the only way to overcome our difficulties and

74. Cuba to Hold Party Congress to Chart Path for Economy, supra note 3.

75. See Cuban People to Discuss Economic and Social Policy Development Project, GRANMA INT'L (Cuba) (Nov. 9, 2010), http://www.granma.cu/ingles/cuba-i/9noviembreCuban\%20people.html; Nick Miroff, Cuba's Rescue Plan Opens Doors to Market Reform, NPR (Nov. 18, 2010), http://www.npr.org/2010/11/18/131413123/cuba-s-rescue-plan-opensdoors-to-market-reforms.

76. Miroff, supra note 75.

77. Trying to Make the Sums Add Up, supra note 70.

78. Partido Comunista de Cuba, Proyecto de Lineamientos de la Polftica Económica y Social del Partido (2010) [hereinafter Proyecto de Lineamientos], available at $\mathrm{http} / / / \mathrm{www}$.prensa-latina.cu/Dossiers/ProyectoLineamientosPCC.pdf.

79. Raúl the Pragmatist, supra note 18. 
preserve the gains of the Revolution, and that as we update our economic model, planning will be paramount, not the market." 80

In addition to the plan, the Cuban government, the largest employer in the nation, declared its intention to lay off over one million workers; by April 1, 2011, 500,000 Cubans were scheduled to lose their jobs, to be followed by another 800,000 workers before $2013 .^{81}$ Eventually, "up to two-in-five Cubans will no longer work for the state." 82 When compared to the current level of self-employment, which is at about $143,000^{83}$ of the 11.2 million citizens, ${ }^{84}$ the magnitude and significance of the layoffs is better understood.

In place of government employment, the government encourages citizens to seek self-employment or create co-operatives with others ${ }^{85}$-a shocking development for a country that, for the last forty years, has not allowed citizens to employ other Cubans, as it is considered exploitation by the Cuban Constitution to have a non-family "employee." ${ }^{86}$ The 178 government-approved forms of self-employment include eighty-three professions in which non-relative employees may be hired and twentynine previously unauthorized professions and consist of a wide range of professions, including food vendors, sports trainers, stonemasons, bookkeepers, auto body workers, and other various trades. ${ }^{87}$ In exchange for working in the private sector, the self-employed will pay taxes ranging from twenty-five to fifty percent of their personal income. ${ }^{88}$

The changes proposed by Cuba differ markedly from those of the past, ${ }^{89}$ raising questions about the future trajectory of this reform. This is especially so if Cuba eventually becomes a hybrid or market-based

80. PROYeCTO DE LineAmientos, supra note 78 , at 7 ("La política económica en la nueva etapa se corresponderá con el principio de que sólo el socialismo es capaz de vencer las dificultades y preservar las conquistas de la Revolución, y que en la actualización del modelo económico, primará la planificación y no el mercado.").

81. Raúl the Pragmatist, supra note 18.

82. Id.

83. Cuba Starts Process of Reform in 2010, XINHUA NEWS (Nov. 24, 2010, 4:30 PM), http://big5.xinhuanet.com/gate/big5/news.xinhuanet.com/english2010/business/2010-

11/24/c_13620651.htm.

84. Background Note: Cuba, supra note 34.

85. Trying to Make Sums Add Up, supra note 70.

86. Id.

87. Leticia Martínez Hernández, The Self-Employed Sector: Much More than an Alternative, GRANMA INT'L (Cuba) (Sept. 27, 2010), http://www.granma.cu/ingles/cubai/27septiembre-3acpropia-a.html.

88. Cuba Sets Out Rules and Taxes for Self-Employed Workers, BBC NEwS (Oct. 26, 2010, 5:02 PM), http://www.bbc.co.uk/news/world-latin-america-11625472.

89. See Hernández, supra note 87 (explaining the reforms are "also an attempt . . . to distance [Cubans] from those concepts that almost condemned self-employment to extinction and stigmatized those who decided to legally join that sector in the 1990 s"). 
economy. Despite such conjecture, the Cuban government remains committed to its Marxist-Leninist roots; in the words of Marino Murillo Jorge, the Cuban Economic and Planning Minister, "[t]here is no reform, it is an update of the economic model. No one thinks that we are going to turn over property: we are going to administer it in another way." Juan Triana, an economist at the University of Havana, declared these economic reforms are the most important for Cuba since 1975, because "[i]t reaffirms the revolutionary essence of our political system, but changes the philosophy of our economic management." Ultimately, the Cuban government, out of necessity, aims to restructure its economic system to increase the now-lacking productivity and efficiency that continue to plague the country and to counterbalance many fundamental benefits provided by the Cuban government, including free health care and education, all within the context of its current political ideology. ${ }^{92}$ As such, Cuba remains resolute in its resistance to the predominant models of globalization, and due to the flexibility of globalization, it will be able to do so.

\section{B. Global Changes}

In addition to massive changes to the Cuban economic model, other changes around the world occurred that undoubtedly affected the Cuban policies, including the economic crisis that peaked in 2008. ${ }^{93}$ Additionally, the election of Barack Obama ushered in a possible era of improved relations with Cuba, as the President commented that he looked forward to "a new era of partnership." This resulted in policies that eased travel restrictions to Cuba by Cuban Americans and limitations on the importation of food and medicine to Cuba and travel to Cuba to sell goods. ${ }^{95}$ Although these changes occurred, the United States blockade against Cuba remains, and most likely will continue to

\footnotetext{
90. Cuba Starts Process of Reform in 2010, supra note 83.

91. Miroff, supra note 75.

92. Patricia Grogg, Cubans Queue Up for Copies of New Self-Employment Rules, IPS NEws (Oct. 26, 2010), http://ipsnews.net/news.asp?idnews=53299.

93. See generally Shares Hit By Recession Worries, BBC NEws (Oct. 24, 2008, 10:57 PM), http://news.bbc.co.uk/2/hi/business/7688202.stm (describing the extent of economic loss worldwide).

94. Obama's New Cuba Policy, CBS News (June 26, 2009, 5:11 PM), http://www.cbsnews.com/stories/2009/04/19/politics/politico/main4954987.shtml.

95. Brian Montopoli, Congress Eases Cuba Travel Restrictions, CBS NEwS (Mar. 11, 2009, 11:25 AM), http:/www.cbsnews.com/8301-503544_162-4858977-503544.html; see also Mark Memmott, Visitors to Cuba from U.S. on Pace Not Seen Since the 50's, NPR (Dec. 14, 2010, 3:28 PM), http://www.npr.org/blogs/thetwo-way/2010/12/14/132057364/ visitors-to-cuba-from-u-s-on-pace-not-seen-since-the-50s.
} 
remain until Cuba becomes more "democratic,"96 despite pressure from the United Nations General Assembly, ${ }^{97}$ members of the United States Congress, ${ }^{98}$ and even the U.S. public ${ }^{99}$ to end the decades-old embargo. Indeed, in the face of positive gains that promise better ties with Cuba in the future, Raúl Castro deemed the changes "fine"100 and claimed that the embargo remains without political or moral justification and that Cuba is unwilling "to negotiate our sovereignty nor our political and social system, and our right to self-determination and internal affairs." ${ }^{101}$ As such, Cuba remains resistant to the capitalist model of engagement espoused by the United States.

In addition to increased pressure to fully harmonize Cuba with the global market through changes in United States-Cuban policy, another important development in the context of globalization is the growth of the Chinese economy. China has been growing by an average of more than ten percent per year for the last ten years; it is the world's thirdlargest economy $\mathrm{y}^{12}$ and has strengthened its links to Cuba's economy, as evidenced by trade and commercial ties between the two countries. ${ }^{103}$ Yet, Cuba is not following any one model; instead, this engagement by Cuba as a global actor is dispositive of the flexibility of globalization.

\section{Globalization AND Change in CUBA}

As Cuba trends against some scholars' expectations, the focus now shifts to the reasons behind Cuba's policies, the role of globalization in Cuba's decisions, and what this teaches us about globalization and the role of the state. Finally, this paper puts forth three essential tenets to

96. See Obama Eases Cuba Travel Restrictions, CNN (Apr. 13, 2008, 4:25 PM), http://www.cnn.com/2009/POLITICS/04/13/cuba.travel.

97. See MacFarquhar, supra note 48.

98. Obama Eases Cuba Travel Restrictions, supra note 96 (noting a bill sponsored by several Senators, including Richard Lugar (R-Indiana) and Byron Dorgan (D-North Dakota), to lift the travel ban against Cuba).

99. Id. (citing CNN poll that "seventy-one percent of Americans think that the United States should re-establish diplomatic relations" and sixty-four percent support lifting the travel ban for all Americans entirely).

100. Will Weissert, Raul Castro: Obama's Cuba Policy Changes 'Minimal', GUaRdian (Apr. 29, 2009), http://www.guardian.co.uk/world/feedarticle/8481185.

101. Id.

102. Shamim Adam, China to Exceed U.S. by 2020, Standard Chartered Says, BlOOMBERG BUS. WK. (Nov. 14, 2010, 11:53 PM), http://www.businessweek.com/news/ 2010-11-14/china-to-exceed-u-s-by-2020-standard-chartered-says.html.

103. See China, Cuba Vow to Push Forward Ties to New High, XINHUa News (Nov. 24, 2010), http://news.xinhuanet.com/english2010/china/2010-11/24/c_13620895.htm; Cuba Inspired by China's Economic Reform, supra note 14. 
the Cuban ideology that must be reaffirmed and used as guidance as Cuba controls its entry into globalized society.

\section{A. Theories for Change}

Cuba is changing its economic policies, and this change marks a turning point in Cuban economic policy in the past half-century. It is equally clear that the driving forces of these policies are both internal and external, as Cuba struggles with pressures from the outside global market, natural disasters, and foreign relations while coping with increasing domestic problems of inefficiency, scarcity of resources, and political change within its own borders. Truly, the changes occurring in Cuba are a result of globalization, as external processes and internal forces transform Cuba and, at the same time, as Cuba participates in the transformation process itself in its implementation of new policies.

In response to the proposed economic reforms, several theories emerged with explanations for the true reason for Cuba's policies. As previously stated, Cuba is a different state; it would seem natural for Cuba to be immune to global pressure. Yet, Cuba finds its own ways to globalize. Although the explanations put forth by various commentators present an incomplete analysis of changes that, while significant, remain firmly attached to Marxist-Leninist doctrine, these explanations, when presented in the context of globalization, illuminate both the Cuban policies and the continued evolution of globalization, presenting another generation of globalization. ${ }^{104}$ While the three theories presented here-(1) that Cuba globalizes out of necessity; (2) that Cuba globalizes to prepare its government for the post-Castro transition; and (3) that Cuba globalizes due to internal pressure - each fails to provide a complete explanation for the Cuban economic reforms; they illustrate generally the role of the state as an actor in a globalized world.

\section{Cuba Globalizes Out of Necessity}

This first theory for change is that Cuba, rather than readily doing so of its own free will, globalizes out of pure necessity. As previously

104. Here, I mean another generation of globalization in the context of globalization itself, evolving as the states themselves globalize; that is, globalization changes with time, with world events, too. This is not to be confused with the terms coined by Thomas Friedman-Globalization 1.0, 2.0, 3.0-as Friedman's terms are specific to different, specific changes in the understanding of globalization. See THOMAS FRIEDMAN, THE WORID is Flat: A BRIEF HISTORY OF THE TWENTY-FIRST CENTURY 10 (2d rev. and expanded ed. Picador 2007) (2005). 
discussed, the current economic state of Cuba is dire, leading some to argue that Cuba enacts these changes due to its economic distress after years spent as a "bloated and paternalistic state." 105 Under this theory, Cuba adopts a more efficient and streamlined economy because of its past failure rather than out of true enthusiasm for reform, marking a doctrinal turning point for Cuba. ${ }^{106}$

Another argument is that Cuba is globalizing because of pressure from China, a close political and economic ally, ${ }^{107}$ over Cuba's struggles to repay debt. ${ }^{108}$ Looking to the similarities between potential reforms and those used in International Monetary Fund bail outs, ${ }^{109}$ it could be argued that pressure from China to improve Cuba's waning economy drives the adoption of reforms, perhaps leading to the gradual adoption of a system similar to that of China's market socialism.

Although these theories argue that Cuba is becoming more marketbased and less based in Fidelismo, they are understood more appropriately as the acknowledgment by Cuba that it no longer can remain isolationist in a globalized world. Additionally, while it seems that Cuba is eager to learn from the Chinese experience, ${ }^{110}$ it does not appear that Cuba globalizes its economy or mirrors the Chinese hybrid system simply to motivate China to "further loosen[ its purse strings." In the context of globalization, these changes are a result of global harmonization ${ }^{12}$ with common practices, rather than an acknowledgment of ideological defeat, and they reiterate that the state, even while resistant to predominant models of globalization, can refigure itself to globalize in its own model.

105. Trying to Make the Sums Add Up, supra note 70.

106. Id. ("Raúl Castro and his allies have clearly won [the debate], against the more doctrinaire officials promoted by Fidel Castro after he abandoned the limited opening of the 1990s.").

107. See Cuba Inspired by China's Economic Reform, supra note 14 ("[W]ith the fall of the Soviet Union [Cuba] drew closer to Beijing, which in 2009 was the main supplier of consumer and manufactured goods to the Caribbean island."); Marc Frank, Cuba Bows to Pressure to Reform its Economy, FIN. TIMEs (Dec. 13, 2010, 5:32 PM), http://www.ft.com/cms/s/0/e6fc637406d9-11e0-8c29-00144feabdc0.htm\#axzz18g1V0No5 (referring to China's status as Cuba's second largest creditor).

108. Frank, supra note 107 (citing analysis that Cuba's debt exceeds $\$ 21$ billion dollars, which is close to fifty percent of gross domestic product and Cuba's rescheduling of its debt); see also Cuba to Restructure Its External Debt with China, LA DEMAJAGUA (Dec. 21, 2010, 10:18 AM), http://www.lademajagua.co.cu/ingles/index.php/cuba-news/1673-cuba-torestructure-its-external-debt-with-china.

109. Frank, supra note 107.

110. Id. (quoting a Cuban official that "Cuba is prepared to take advantage of China's experience in developing reform and opening up").

111. Id.

112. Backer, supra note 7 , at 411 ("Global harmonization produces pressures that nations like Cuba may find difficult to resist."). 


\section{Cuba Globalizes to Prepare Its Government for the Post-Castro Transition}

Another theory looks to the age of the Cuban government as a motivation for the changes, perhaps arguing that the aging ${ }^{113}$ Castro brothers are preparing their country for transition into a new economic model after their deaths. ${ }^{14}$ With Fidel, the backbone of Cuban isolationism, no longer in power, perhaps Raúl, the more open-minded, pragmatic ruler, aims to institute reforms to prepare for the inevitable death of the revolutionary leaders. In addition to aging leaders, there is also the concern of aging ideas and whether the Cuban model is outdated and in need of updating.

Backer emphasizes that the Cuban "vocabulary has become increasingly antiquated, even by Marxist-Leninist standards," something that led to isolation even amongst Communist states such as China and Vietnam. ${ }^{115}$ Although in 2004 it seemed that Cuba was "increasingly unable or unwilling to understand changes in other Marxist-Leninist states," 116 today, it seems that Cuba is admittedly willing to "take advantage" of the reforms of other Communist countries $^{117}$ and has opened the opportunity for dialogue regarding the possible benefits or shortcomings of the Chinese system as applied to Cuba. Moreover, while the influence of other Communist states that utilize a hybrid system may provide guidance, Cuba remains committed to socialism as it implements changes ${ }^{118}$ and insists that Cuba is not copying any other models in its reforms. ${ }^{119}$

Within the context of globalization, concerns regarding the aging leadership and outdated economic policies obviously influence Cuban policies, so they may be harmonized better with the global market. In addition, Cuba's close relationship with China may partially influence how Cuba chooses to update its policies. Cuba is reforming its

113. Fidel Castro is 84 years old and Raúl Castro is 79 years old as of 2010 . Profile: Raul Castro, BBC NEWS (Mar. 14, 2011, 11:10 AM), http://news.bbc.co.uk/2/hi/5234790.stm.

114. See Trying to Make the Sums Add Up, supra note 70 ("So are the Castro brothers, in the twilight of their lives, preparing to lead Cuba towards a mixed economy, similar to that of China?").

115. Backer, supra note 7 , at 406.

116. Id.

117. Frank, supra note 107 (quoting a Cuban official that "Cuba is prepared to take advantage of China's experience in developing reform and opening up").

118. PROYECTO DE LINEAMIENTOS, supra note 78, at 6 ("[S]ólo el socialismo es capaz de vencer las dificultades y preservar las conquistas de la Revolución" (Socialism is the only way to overcome our difficulties and preserve the gains of the Revolution).).

119. Raúl's Talking Cure, supra note 12. 
admittedly antiquated policies ${ }^{120}$ in order to withstand a change in power; in doing so, it will remain a powerful actor in its emerging global economy. In short, to succeed, the government must continue to bring Cuba into the global market so that it may continue to strengthen its links with other countries, organizations, and networks, yet, in doing so, the government must also choose the manner and mode of global engagement.

\section{Cuba Globalizes Due to Internal Pressure}

A final presented theory is that the economic reforms merely legalize already-existing informal private enterprises that were formerly prohibited. ${ }^{121}$ While it could be argued that this reason undercuts the legitimacy of the decision or shows the weakness of the Cuban government, in the context of globalization, internal pressures are an acknowledged, powerful force in the decision-making process of the state. Internal pressures, whether based on linkages between citizens down the street or across the world, influence the decisionmaking of a state as much as forces from other states or international groups. ${ }^{122}$

In Cuba, there has long been internal criticism of "the centralizing, state-monopolistic, and bureaucratized form of Marxist-Leninism represented by Stalinist Cuba." 23 Dissent, even where citizens have limited access to the Internet ${ }^{124}$ and freedom of assembly, ${ }^{125}$ and actions taken by citizens, such as Cuban emigration due to a lack of earning potential, ${ }^{126}$ is a forceful internal, globalizing pressure that the Cuban government must and will address through its decision-making process. Rather than weakening, due to this pressure, the Cuban state evolves itself into an involved global actor.

120. Hernández, supra note 87 ("[The reforms are] also an attempt . . . to distance ourselves from those concepts that almost condemned self-employment to extinction and stigmatized those who decided to legally join that sector in the 1990s.").

121. Trying to Make the Sums Add Up, supra note 70 ("One way of interpreting the changes is that rather than creating new opportunities, they merely legalise what was already a widespread informal economy of clandestine private enterprise.").

122. See Held et al., supra note 19, at 67-68.

123. Backer, supra note 7 , at 412.

124. Background Note: Cuba, supra note 34 ("[A]ccess to the Internet is strictly controlled ....").

125. Id. ("The law punishes unauthorized assembly of more than three persons.").

126. Rory Carroll, Cuba Suffers Exodus of the Best and the Brightest as Economy Remains in the Doldrums, GUARDIAN (May 8, 2010), http://www.guardian.co.uk/world/ 2010/may/09/cuba-raul-castro-emigration (noting that "[y]oung people, especially welleducated professionals, are fleeing the island"). 


\section{B. Globalization: the Cause and the Answer}

Ultimately, all of the forces found in these theories make it difficult for a state like Cuba to resist change, as predicted by Larry Catá Backer. ${ }^{127}$ Moreover, globalization itself accounts for all of these changes-it is both the transformative trigger and the answer to Cuba's motivation to reform. From a case study of Cuba, a historically resistant country, the overwhelmingly unavoidable nature of globalization becomes obvious; in the words of Fidel Castro, globalization is an "inevitable phenomenon." 128 However, the mere fact that globalization is inescapable for Cuba does not mean that Cuba must change its ideological basis or goals in order to globalize; Castro conditioned his declaration by saying that globalization was not inevitable if it was an imposition of neoliberal globalization. ${ }^{129}$ Today, under the leadership of Raúl Castro, it is clear that, contrary to Backer's 2004 prediction, a fundamental change of ideology is not a requisite for Cuban reform. ${ }^{130}$ Instead, Cuba changes its economy within the context and the understanding of its own Marxist-Leninist goals, rather than mirroring the Chinese or the neoliberal forms of globalization.

The very fact that Cuba is reluctant to globalize or is not globalizing for altruistic, market-based reasons does not negate the significance of its reforms. Indeed, the importance of the reforms is that Cuba, as a state, decides to implement changes, albeit in a new model, to remain in power and to engage the global economy. Moreover, in the context of globalization, the fact that these changes are not accompanied with fundamental changes to the Cuban Marxist-Leninist framework is an even stronger argument that global harmonization does not require ideological homogenization, linear changes, or a simplistic one world model. Globalization is infinitely flexible, complex, and diverse.

Globalization in today's world no longer requires homogenization; Cuba does not need to either adopt a neoliberal or Maoist version of economics to globalize. Instead, it can remain Marxist-Leninist while entering into the global economy. Just as neoliberal policies are not the

127. Backer, supra note 7, at 411-12 ("Together, these forces are difficult to resist for states that are small, poor, of and in a technologically inferior position.").

128. Fidel Castro, Capitalism in Crisis: Globalization and World Politics Today 46 (David Deutschmann ed., 2000).

129. Id. at 101.

130. Larry Catá Backer, Cuba Responds to Globalizationand [sic] Reorganizes Its Political Economy, L. END DAY (Sept. 24, 2010, 7:09 PM), http://cbackerblog.blogspot.com/ 2010/09/cuba-respondes-to-globalization-opening.html ("[T] he great changes to the Cuban political economy assumes a coherent shape that is hardly revolutionary or that otherwise points to a rejection of its current framework. This is change at the margins, even if understood as significant within the framework of Cuban political thinking."). 
only concept of globalization, as seen in China, so too Chinese Maoism is not the only alternative form of globalization. The fundamental differences between China and Cuba are vast-for example, the focus of the Cuban reform differs from that of the Chinese, ${ }^{131}$ the decision by Cuban officials to shun Chinese "market socialism"132 in favor of limited Communist reforms, ${ }^{133}$ and the histories and cultures of the two countries differ. ${ }^{134}$

Cuba presents a different story of globalization-one of a nation, rather than making an ideological change without regard to outside circumstances, instead shifting policies out of necessity and the need to survive in a changed world. Moreover, Cuba's story of globalization is one of a nation attempting to limit negative effects of globalization. Cuba, while symbolically isolated for the last sixty years, was not immune from globalization-the country's resistance wreaked havoc upon the economic and social growth of the nation. Instead, Cuba, as a global actor, reconfigures itself to retain power in its new model of global engagement. And yet, Cuba's decision to gradually reform economic policies is not made in isolation; while Raúl Castro certainly makes the decisions, many of these decisions have already been made for Cuba by a globalized world.

Upon review, Cuba will retain its ideological goals without completely compromising or adhering to the other forms of governance-this is what globalization means, the permeation of even the most historically uncompromising country and the harmonization of certain key ideas and practices embraced by the rest of the world. Moreover, it shows that globalization does not stop with market-based or neoliberal governance; instead, as Deng Xiaoping stated, "[The] [m]arket can also serve socialism." ${ }^{135}$ Although Cuba certainly will stop

131. Id. (commenting that "[t]his is no revolution" in the Cuban policies, which, unlike the Chinese focus on aggregation of capital or labor, focus upon large scale economics in which the Cuban state remains a central figure).

132. See David Dollar \& Aart Kraay, Spreading the Wealth, in THE GLOBAL TRANSFORMations READER: AN INTRODUCTION TO THE GLOBALIZATION DEBATE 447, 450 (David Held \& Anthony McGrew eds., 2d ed. 2003) (exploring the validity of the antiglobalization movement).

133. Raúl the Pragmatist, supra note 18 (No Cuban official has matched Deng Xiaoping's embrace of 'market socialism', let alone his (perhaps apocryphal) injunction that 'to get rich is glorious'.").

134. See Jiang Shixue, Chinese Acad. of Soc. Sci., Cuba's Economic Reforms in A Chinese Perspective, Paper Presented to the Wilton Park Conference on Cuba (Oct. 2002), available at http://blog.china.com.cn/jiangshixue/art/915280.html ("[The Deng Xiaoping Theory's] essence is to build socialism with Chinese characteristics. . . . As socialist countries, Cuba and China should have their own values compatible to their political system and traditional cultures.").

135. Id. 
short of embracing market socialism, it is engaging economic globalization as a global actor. ${ }^{136}$ The state can carve out niches for globalization; however, the question remains how Cuba and other states can limit the undesirable aspects of globalization-here, the neoliberal parts-while benefitting from the harmonization of globalization.

\section{Limiting Globalization-Essential Constitutional Reaffirmations}

The Cuban Constitution provides a robust and resolute ideological declaration of the fundamental Cuban tenets of governance, including equality, dignity, and socialism. ${ }^{137}$ However, in light of the potential challenges of limiting globalization to coincide with and benefit the people and ideological basis of Cuba, it is important to reaffirm certain essential constitutional principles relating to the economic reform; in doing so, Cuba may help define the boundaries for globalization and identify the ways Cuban globalization differs from that of Maoist or neoliberal countries. While there are many important aspects of the Cuban ideology, this paper proposes three that are so central to the very principles of Marxist-Leninist philosophy that, in light of economic reforms, should be explicitly reaffirmed by the Cuban government. Cuba cannot wither as a state, nor can its economic policy undercut its core societal values.

The first principle is that of the sovereignty of the state over the economic activities within Cuba. According to Article Sixteen of the Cuban Constitution, the role of the state is to organize, to direct, and to control such economic activity to guarantee "the programmed development of the country, to strengthen the socialist system of satisfying the material and cultural needs of the society and citizens, to promote the development of human beings and their dignity, [and] the progress and the security of the country." 138 The Cuban government

136. Rory Carroll, Capitalist Storm Clouds Loom over Havana after State Cuts $1 \mathrm{~m}$ Jobs, GUARDIAN (Sept. 14, 2010, 5:00 PM), http://www.guardian.co.uk/world/2010/sep/14/cubagovernment-job-cuts-private-sector (noting Julia Sweig's analysis that "[a] hybrid is evolving which can't be said to be any one thing .... We're seeing a uniquely Cuban transition but within the global economy").

137. CONSTITUCIÓN DE LA REPÚBLICA DE CUBA 2002, pmbl. ("Conscientes ... de que sólo en el socialismo y el comunismo, cuando el hombre ha sido liberado de todas las formas de explotación: de la esclavitud, de la servidumbre y del capitalismo, se alcanza la entera dignidad del ser humano; y de que nuestra Revolución elevó la dignidad de la patria y del cubano a superior altura ....").

138. Id. art. 16 ("El Estado organiza, dirige y controla la actividad económica nacional conforme a un plan que garantice el desarrollo programado del país, a fin de fortalecer el sistema socialista, satisfacer cada vez mejor las necesidades materiales y culturales de la 
must make it clear that it remains firmly in control of the economy, including any "privatization" through self-employment; that, unlike Chinese market-based Maoism, the government is the sole regulator of the economy; and that the government protects the interests and dignity of individuals and, therefore, that any "privatization" aims must serve that same goal.

The second principle is the continued abhorrence of consumerism and prohibition of class augmentation. Article Fourteen of the Cuban Constitution conditions ownership of goods and land upon the principle of equality and the prevention of exploitation of individuals. ${ }^{139}$ These constitutional principles also carry into affirmative guarantees of work, disability, social assistance, occupational protections, and health care ${ }^{140}$ that are based upon presumptions of fairness and justice. ${ }^{141}$ Contrary to the linear models that claim society must compromise values to accommodate economic growth, Cuba will remain resolute. Therefore, the Cuban government must reaffirm these ideals in the context that globalization serves to benefit the whole, rather than to enrich a select class; the same principles of egalitarianism upon which Cuba stands must be reaffirmed to set apart the Cuban economic reforms from those of Maoist or neoliberal countries.

The final principle is that Cuba must reiterate and must focus its policies on the bedrock of the nation-socialism. As described in the Cuban Constitution, socialism is transformative in creating a "new and just society, [socialism] is irrevocable, and Cuba will never return to capitalism." 142 By maintaining the view that Cuba's globalization occurs within the larger framework of Cuba's socialist ideology, Cuba can effectively protect itself from possible neoliberal policies that threaten the core of its system. Cuba may globalize effectively without changing its ideology; it must make it abundantly clear that "the only globalization that can save humanity and preserve the human species is

sociedad y los ciudadanos, promover el desenvolvimiento de la persona humana y de su dignidad, el avance y la seguridad del país.").

139. Id. art. 14 ("En la República de Cuba rige el sistema de economía basado en la propiedad socialista de todo el pueblo sobre los medios fundamentales de producción y en la supresión de la explotación del hombre por el hombre. También rige el principio de distribución socialista 'de cada cual según su capacidad, a cada cual según su trabajo'.”).

140. Id. arts. 47-50.

141. Id. art. 41 ("Todos los ciudadanos gozan de iguales derechos y están sujetos a iguales deberes.").

142. Id. art. 3 ("El socialismo y el sistema político y social revolucionario establecido en esta Constitución, probado por años de heroica resistencia frente a las agresiones de todo tipo y la guerra económica de los gobiernos de la potencia imperialista más poderosa que ha existido y habiendo demostrado su capacidad de transformar el país y crear una sociedad enteramente nueva y justa, es irrevocable, y Cuba no volverá jamás al capitalismo."). 
a socialist globalization." ${ }^{143}$ Thus, Cuba allows for harmonization essential to the maintenance of the Cuban economy without betraying the foundational elements of the Cuban identity.

In reaffirming the central tenets of Cuba's ideology, Cuba may take charge of its globalization and carefully guide its citizens into the global economy without exposing itself to the possible pitfalls of neoliberal globalization.

\section{CONCLUSION}

Ultimately, the available explanations for Cuban economic changenecessity, age, and economics-fail to capture the reason for and the significance of the Cuban economic reform. Cuba, a nation that would seemingly resist globalization altogether, is reconfiguring itself as a state to remain in power in a globalized world. The State of Cuba remains ever-important to the decisions made regarding the state's policies; for that, the predominate models of globalization cannot and will not be implemented in Cuba. As Cuba remains in power by choosing to globalize differently than the other models, it reveals the incredible malleability of globalization. Globalization is not about a one world model, nor is it about a few templates for engagement; rather it creates, embraces, and elevates differences, linkages, and interplay between countries.

Indeed, globalization is a powerful, transformative force that prevents any state from remaining in isolation if it hopes to survive. It is also a force that does not require homogenization for states to integrate into the global community. Cuba's policies, if successful, will provide it with the requisite stability to engage in the global economy. ${ }^{144}$ Cuban reform shows that the state, as an actor, may remain ideologically resolute, yet alter its economy to enter into a globalized society. Certainly, globalization does not mark the end of socialist Cuba, but instead draws all parties in the global economy to common engagement to succeed.

143. CASTRO, supra note 128 , at 46.

144. Larry Catá Backer, Operationalizing Cuba's New Economic Model: The New Regulations Are Published, L. END DAY (Oct. 26, 2010, 10:17 PM), http:// lcbackerblog.blogspot.com/2010/10/operationalizing-cubas-new-economic.html ("If the Cuban government can make this work they will go a long way to achieving a measure of stability that may withstand the impact of Cuba's reentry into the conventional global economy."). 